\title{
ZESPÓŁ DZIECKA MALTRETOWANEGO \\ A OBOWIĄZEK DOCHOWANIA TAJEMNICY LEKARSKIEJ
}

\section{Wprowadzenie}

Dziecko, jako istota ze swej natury nieporadna, powinno być otoczone szczególną troską nie tylko rodziców bądź opiekunów, ale również państwa. Oznacza to, że dziecko podlega ochronie prawnej, którą gwarantują akty normatywne różnej rangi. W myśl przepisu art. 72 ust. 1 Konstytucji Rzeczypospolitej Polskiej z dnia 2 kwietnia 1997 r. ${ }^{1}$ Rzeczpospolita Polska zapewnia ochronę praw dziecka przed przemocą, okrucieństwem i demoralizacją. Rodzice realizując powinności i zadania wynikające $z$ faktu rodzicielstwa powinni kierować się dobrem dziecka. A zatem dobro dziecka - zgodnie z art. 93 ustawy z dnia 25 lutego 1964 r. - Kodeks rodzinny i opiekunczy ${ }^{2}$ - powinno być traktowane jako wartość priorytetowa. Nie zawsze jednak tak się dzieje. Coraz częściej zdarzają się nadużycia skierowane przeciwko najmłodszym. Co kilka dni środki masowego przekazu informują społeczeństwo o niezwykle brutalnych czynach popełnianych na szkodę najmłodszych, np. pobicie ze skutkiem śmiertelnym, znęcanie się fizyczne czy psychiczne, wykorzystywanie seksualne. Co więcej, czyny te popełniane są niejednokrotnie przez osoby dziecku najbliższe, którymi są przede wszystkim ci rodzice, którzy destrukcyjnie wpływają na jego psychikę, samoocenę, a także powodują, że dziecko czuje się winne zachowania

* Dr, Uniwersytet Humanistyczno-Przyrodniczy im. Jana Długosza w Częstochowie; e-mail: m.bartnik@ujd.edu.pl.

1 Konstytucja Rzeczypospolitej Polskiej z dnia 2 kwietnia 1997 r., Dz. U. z 1997 r. Nr 78, poz. 483 z późn. zm. i sprost. (dalej: Konstytucja RP).

2 Ustawa z dnia 25 lutego 1964 r. - Kodeks rodzinny i opiekuńczy, tekst jednolity: Dz. U. z 2017 r. poz. 682 z późn. zm. (dalej: k.r.o.). 
rodziców. To pozwala stwierdzić, że sferą, w której ochrona praw dziecka uzewnętrznia się najbardziej, jest prawnokarna ochrona dobra dziecka.

Celem artykułu jest, po pierwsze, zwrócenie uwagi na konieczność podejmowania współpracy pomiędzy lekarzami a organami ścigania w przypadku zespołu dziecka maltretowanego (przy czym nie wystarczy tutaj tylko i wyłącznie działanie represyjne); po wtóre - wykazanie, iż instytucja tajemnicy lekarskiej nie stanowi przeszkody do zawiadomienia organów ścigania w przypadku podejrzenia zespołu dziecka maltretowanego; po trzecie - przypomnienie, że nieudzielenie pomocy człowiekowi, którego życie jest zagrożone, będzie skutkowało pociągnięciem lekarza do odpowiedzialności prawnej, bowiem ma on obowiązek udzielić pomocy lekarskiej w każdym przypadku.

\section{Dziecko}

Przybliżenie zagadnienia podjętego $\mathrm{w}$ temacie niniejszego artykułu wymaga zdefiniowania podstawowych pojęć takich, jak: „dziecko”, ,dobro dziecka” oraz „zespół dziecka maltretowanego”.

Termin "dziecko" jest przedmiotem badań wielu dyscyplin naukowych, m.in. pedagogiki, psychologii, socjologii, medycyny, a także prawa. Nauki te posługują się rozmaitymi definicjami w zakresie pojmowania omawianego terminu.

Współcześnie terminem dziecko określana jest osoba do 18 roku życia $^{3}$. Bez ryzyka błędu należy stwierdzić, że zakres stosowanej w języku codziennym definicji dziecka jest czytelny i zrozumiały dla wszystkich. Podkreślić należy, że oprócz rozpatrywanej przez pryzmat granicy wieku definicji dziecka, istnieje jeszcze jedna, odnosząca się do stosunków pomiędzy rodzicami a dziećmi, w świetle której dzieckiem jest każdy potomek w stosunku do swoich rodziców. To pozwala przyjąć, że termin „dziecko" utożsamiany jest zarówno z pewnym okresem życia, jak i ze stanem niedojrzałości fizycznej i psychicznej. Chodzi zatem o osobę, która ze względu na wiek nie osiągnęła jeszcze samodzielności i nie jest zdolna, by za siebie odpowiadać. Termin „dziecko" ma więc zawsze dwa znaczenia. W świetle pierwszego z nich dzieckiem jest człowiek od urodzenia aż

3 Zob. M. Balcerek, Prawa dziecka, Warszawa 1986, s. 22; M. Szymczak (red.), Stownik jezzyka polskiego, t. 1, Warszawa 1981, s. 498. 
do chwili uzyskania pełnoletności. Natomiast drugie znaczenie nie wiąże się z wiekiem - przyjmuje się, że dzieckiem jest każdy potomek w stosunku do swoich rodziców.

Przywołane definicje pozwalają stwierdzić, że między dzieckiem a osobą dorosłą zauważalne są nie tylko różnice ilościowe (np. niski wzrost, mała waga), ale również jakościowe (np. cechy spostrzegania, sposób wysławiania się, sposób pojmowania sytuacji i zjawisk zachodzących wokół niego). Dlatego tak ważny jest odmienny sposób traktowania dziecka i osoby dorosłej, nie tylko w trakcie np. prowadzonego w postępowaniu karnym przesłuchania, ale także w życiu codziennym. Na dzieci nie należy przerzucać obowiązków osób dorosłych, które nadmiernie je obciążą, a tym samym pozbawią możliwości korzystania z radosnego dzieciństwa.

Również prawo regulując zagadnienia poświęcone dziecku jako podmiotowi korzystającemu $\mathrm{z}$ ochrony prawnej posługuje się tym terminem w celu określenia granicy bycia dzieckiem. Należy jednak podkreślić, że stosowane przez jurystów pojęcie „dziecka” - w zakresie bogactwa treści i wykorzystania zakresu tej definicji - będzie się diametralnie różnić od stanowiska psychologów, pedagogów czy też socjologów $w^{4}$. Prawnicy traktując o dziecku, zważywszy na stan zależności od rodziców lub opiekunów prawnych, niepełną samodzielność, a także brak możliwości podejmowania decyzji wywołujących skutki prawne, skupiają swoją uwagę na wynikającym bezpośrednio z obowiązujących przepisów prawa statusie prawnym dzieci ${ }^{5}$. Najszersza definicja terminu "dziecko" zawarta została w art. 2 ust. 1 ustawy z dnia 6 stycznia 2000 r. o Rzeczniku Praw Dziecka ${ }^{6}$, w świetle której: „[...] dzieckiem jest każda istota ludzka od poczęcia do osiągnięcia pełnoletności". Podobną definicję przewiduje regulacja pomieszczona w art. 1 Konwencji o prawach dziecka ${ }^{7}$, zgodnie z którą pojęciem „dziecko” określana jest każda istota ludzka „[...] w wieku poniżej osiemnastu lat, chyba że zgodnie z prawem [...] uzyska ono wcześniej

4 Zob. B.M. Kałdon, Przemoc wobec dziecka w rodzinie. Studium empiryczne z zakresu kryminologii i prawa, Warszawa 2014, s. 84.

5 Zob. A. Łopatka, Kto jest dzieckiem?, [w:] A. Łopatka (red.), Konwencja o prawach dziecka, a prawo polskie. Materiaty z konferencji naukowej zorganizowanej w gmachu Sejmu RP w dniach 19-20 marca 1991 r., Warszawa 1991, s. 18.

6 Ustawa z dnia 6 stycznia 2000 r. o Rzeczniku Praw Dziecka, tekst jednolity: Dz. U. z 2017 r. poz. 922.

7 Konwencja o prawach dziecka, przyjęta przez Zgromadzenie Ogólne Narodów Zjednoczonych dnia 20 listopada 1989 r., Dz. U. z 1991 r. Nr 120, poz. 526 z późn. zm. 
pełnoletność". Z uwagi na problematykę zakreśloną tematem niniejszego artykułu przedmiotem rozważań będzie ostatnie z przytoczonych znaczeń, zgodnie z którym dzieckiem jest człowiek od chwili poczęcia aż do osiągnięcia pełnoletności.

Kolejnym terminem, który wymaga przynajmniej krótkiej refleksji, a który pozostaje nierozłącznie związany z dzieckiem jako podmiotem prawa, jest „dobro dziecka”. Dziecko na każdym etapie rozwoju wymaga szczególnej opieki i troski przede wszystkim ze strony rodziców, którzy tworząc podstawową komórkę społeczną, jaką jest rodzina, mają obowiązek zapewnić każdemu ze swoich dzieci odpowiednie warunki bytowe, socjalne, kulturalne itp., ponieważ nadrzędnym interesem, który ma zostać zrealizowany, jest właśnie interes dziecka. Teza ta znajduje odzwierciedlenie m.in. w Preambule do Konwencji o prawach dziecka. Obowiązek zaspokojenia potrzeb życiowych dziecka nie oznacza, że rodzicom przysługuje nieograniczona władza nad nim. Przeciwnie, władza ta musi mieścić się w pewnych granicach, które wyznacza właśnie klauzula dobra dziecka. Należy zauważyć, że do rodzimego porządku prawnego pojęcie "dobra dziecka”, a tym samym wymóg kierowania się dobrem dziecka, wprowadzone zostały w $1946 \mathrm{r}$. na mocy dekretu o stosunkach rodzinnych ${ }^{8}$. Zgodnie z art. $20 \S 3$ dekretu obowiązkiem rodziców jest wykonywanie przez nich władzy rodzicielskiej nad dzieckiem z poszanowaniem zasady dobra dziecka oraz zgodnie z potrzebami społecznymi. Mimo, iż klauzula dobra dziecka obowiązuje ponad 70 lat, a ustawodawca posługuje się nią niezwykle często w przepisach różnej rangi, to nie zdecydował się na "zamknięcie" tego terminu w ramach tzw. definicji legalnej. Identycznie należy ocenić w tym zakresie działalność judykatury i doktryny, które pomimo bogatego orzecznictwa oraz piśmiennictwa poświęconego (bezpośrednio i pośrednio) klauzuli dobra dziecka, ograniczają się jedynie do formułowania wskazówek interpretacyjnych, określających w sposób niewyczerpujący czynniki, które - przy ocenie "dobra dziecka" w konkretnym przypadku - powinny być uwzględnione przez organy wymiaru sprawiedliwości ${ }^{9}$. Słusznie twierdzi W. Stojanowska, iż dobro dziecka to:

8 Dekret z dnia 22 stycznia 1946 r. o stosunkach rodzinnych, Dz. U. z 1946 r. Nr 6, poz. 52 ze sprost. (dalej: dekret).

9 Zob. postanowienie Sądu Najwyższego z dnia 11 lutego 1997 r., II CKN 90/96, Legalis nr 333272; postanowienie Sądu Najwyższego z dnia 12 grudnia 2000 r., V CKN 1751/00, Legalis nr 299530. 
[...] kompleks wartości o charakterze niematerialnym i materialnym, niezbędnych do zapewnienia prawidłowego rozwoju fizycznego i duchowego dziecka oraz do należytego przygotowania go do pracy odpowiednio do jego uzdolnień, dodając, że wartości te są zdeterminowane przez wiele różnorodnych czynników, zależnych od treści stosowanej normy prawnej i aktualnie istniejącej sytuacji dziecka ${ }^{10}$.

Zgodnie ze stanowiskiem prezentowanym przez A. Łopatkę pojęcie „dobro dziecka” obejmuje doraźne jak i długofalowe interesy dziecka ${ }^{11}$. Oznacza to, że dziecko powinno korzystać z ochrony prawnej w każdej sferze życia.

\section{Prawa dziecka a zespół dziecka maltretowanego}

Tematyka ochrony praw najmłodszych nie jest zagadnieniem nowym. Historycznie problematyka krzywdzenia dzieci pojawiła się już w czasach starożytnych, kiedy to ojciec dziecka jako pater familias mógł decydować o losie własnego dziecka. Innymi słowy to pater familias decydował o tym, które dziecko ma żyć, a które może pozbawić życia, ze względu np. na jego kalectwo albo z tzw. przezorności, gdy nadmierny przyrost utrudniał lub uniemożliwiał wyżywienie i wychowanie potomstwa urodzonego poprzednio ${ }^{12}$.

W Polsce zagadnienie „zespołu dziecka maltretowanego” sygnalizowane było już w 1907 r. przez L. Wachholza, który opisał kilka przypadków znęcania się nad dziećmi ${ }^{13}$. Zgodnie $\mathrm{z}$ definicją WHO pod pojęciem „zespołu dziecka maltretowanego" należy rozumieć każde zamierzone lub niezamierzone działanie osoby dorosłej, społeczeństwa lub państwa, które ujemnie wpływa na zdrowie, także rozwój fizyczny lub psychospołeczny dziecka. Zespół dziecka maltretowanego (zwany również zespołem dziecka bitego) jest niezwykle trudny do rozpoznania nie tyle z uwagi na brak obrażeń u dziecka, co ze względu na ustalenie ich etiologii. Krzywdze-

10 W. Stojanowska, Rozwód a dobro dziecka, Warszawa 1979, s. 27.

11 Zob. A. Łopatka, Dziecko, jego prawa człowieka, Warszawa 2000, s. 29.

12 Zob. K. Marzec-Holka, Dzieciobójstwo-przestępstwo uprzywilejowane czy zbrodnia?, Bydgoszcz 2004, s. 11.

13 Zob. L. Wachholz, Dzieci jako ofiary znęcania się rodziców, „Przegląd Lekarski” 1908, nr 9, s. 1-10. 
nie dziecka może następować na różne sposoby: bicia, wykorzystywania seksualnego, przemocy psychicznej, zaniedbywania, opuszczenia, porzucenia, wykorzystywania jako przedmiotu (instrumentu) do zaspokajania własnych potrzeb. Innymi słowy krzywdzenie dziecka może przybrać formę działania bądź zaniechania określonego działania.

W rodzimym porządku prawnym dziecko przed złym traktowaniem chroni przepis art. 207 ustawy z dnia 6 czerwca 1997 r. - Kodeks karny ${ }^{14}$, zgodnie z którym odpowiedzialność karną ponosi ten, kto znęca się fizycznie i psychicznie nad osobą: najbliższą lub inną osobą pozostającą w stałym lub przemijającym stosunku zależności od sprawcy, nieporadną z uwagi na jej wiek lub stan psychiczny lub fizyczny. Formy znęcania, o których mowa w przywołanym przepisie, mogą być różne i - co zostało już wcześniej zasygnalizowane - wyrażać się zarówno w działaniu, jak i zaniechaniu. Jak słusznie zauważa J. Bryk przestępstwo znęcania się nad dzieckiem polega na zadawaniu dolegliwości fizycznych lub psychicznych wykraczających poza granice kontratypu karcenia małoletnich ${ }^{15}$. Nie ulega wątpliwości, że skutki przemocy wobec dzieci są niezwykle poważne. Innymi słowy, do najczęstszych objawów pozwalających na domniemanie wystąpienia zespołu dziecka maltretowanego należą zaburzenia psychiczne i fizyczne. Do pierwszej grupy zalicza się nie tylko m.in. ucieczki z domu, problemy szkolne, alienacje, nerwice, depresje, nieufność, lęk, poczucie bezsensu, fobie, przygnębienie, zachowania agresywne i (lub) destrukcyjne (np. myśli samobójcze), niską samoocenę, poczucie winy, krzywdy, poczucie bliżej nieokreślonego zagrożenia, zachowania przestępcze, ale również perfekcjonizm oraz potrzebę kontrolowania innych. Z kolei w katalogu zaburzeń fizycznych można wyróżnić: drżenie, problemy gastryczne, uporczywe bóle głowy, zawroty głowy, omdlenia, podwyższone ciśnienie krwi, choroby psychosomatyczne. Z punktu widzenia organów prowadzących postępowanie karne zespół dziecka maltretowanego jest niezwykle trudny do stwierdzenia, bowiem osoby bądź instytucje zgłaszające podejrzenie popełnienia przestępstwa z art. 207 k.k. dysponują często jedynie cząstkową wiedzą dotyczącą znęcania się nad

14 Ustawa z dnia 6 czerwca 1997 r. - Kodeks karny, tekst jednolity: Dz. U. z 2018 r. poz. 1600 z późn. zm. (dalej: k.k.).

15 Szerzej na ten temat, zob. J. Bryk, Zagadnienie karcenia nieletnich jako okoliczności wytączającej bezprawność czynu (rozważania na tle przestępstwa znęcania się), „Przegląd Policyjny" 2001, nr 1, s. 57 i nast. oraz przywołana tam literatura. 
dzieckiem, ponieważ wynika ona jedynie z obserwacji dziecka i jego zachowania lub z obserwacji rodziny dziecka. W tym kontekście pojawia się pytanie o granice tajemnicy lekarskiej w sytuacji podejrzenia przestępstwa znęcania się.

\section{Krzywdzenie dziecka a obowiązek dochowania tajemnicy lekarskiej}

Co do zasady - zgodnie z art. 40 ustawy z dnia 5 grudnia 1996 r. o zawodach lekarza i lekarza dentysty ${ }^{16}$ - lekarz ma obowiązek zachowania $\mathrm{w}$ tajemnicy informacji związanych z pacjentem, a uzyskanych $\mathrm{w}$ związku z wykonywaniem zawodu. Słusznie zauważył W. Kulesza twierdząc, że lekarz jako depozytariusz tajemnicy pacjenta zobowiązany jest „,[..] do strzeżenia przed osobami trzecimi powziętej wiedzy nie tylko o stanie zdrowia swego pacjenta, ale o wszystkim, co pacjenta dotyczy: jego stosunkach zawodowych, rodzinnych, emocjonalnych, a także zamiarach, jeżeli były one przedmiotem zwierzeń uczynionych przez pacjenta"17. Należy zatem przyjąć, że dochowanie przez lekarza tajemnicy zawodowej jest po pierwsze jego obowiązkiem, po drugie - odpowiadającym temu obowiązkowi uprawnieniem pacjenta. Nie ulega wątpliwości, że zachowanie $\mathrm{w}$ tajemnicy danych dotyczących rozpoznania u konkretnej osoby nabiera szczególnego znaczenia z tego względu, że ujawnienie jakiejkolwiek informacji dotyczącej stanu zdrowia pacjenta może wywołać negatywne skutki w środowiskach, z którymi pacjent na co dzień jest związany i w których przebywa. Należy jednak z całą odpowiedzialnością stwierdzić, że: „rozpoznanie choroby mającej swą przyczynę w nawet najgroźniejszym zakażeniu powinno być traktowane jak każde inne rozpoznanie z obowiązkiem objęcia go tajemnicą lekarską, [...] nie dopuszczającą wyjątku, który miałby odnosić się - jako rozwiązanie szczególne - do takiego właśnie rozpoznania"18. Tajemnica lekarska nie jest jednak tajemnicą

16 Ustawa z dnia 5 grudnia 1996 r. o zawodach lekarza i lekarza dentysty, tekst jednolity: Dz. U. z 2019 r. poz. 537 z późn. zm. (dalej: u.z.lek.).

17 W. Kulesza, AIDS a prawno karne problemy tajemnicy lekarskiej, [w:] A.J. Szwarc (red.), AIDS i prawo karne, Poznań 1996, s. 69-70.

18 D. Meurer, AIDS und strafrechtliche Probleme der Schweigepflicht, [w:] A.J. Szwarc (red.), AIDS und Strafrecht, Berlin 1996, s. 133-153, cyt. za: W. Kulesza, AIDS a prawno karne..., s. 70. 
bezwzględną. Przesądzają o tym regulacje zawarte $\mathrm{w}$ przepisach art. 40 ust. 2 u.z.lek. (co jest zgodne z art. 25 Kodeksu Etyki Lekarskiej ${ }^{19}$ ), według których lekarz nie ma obowiązku zachowania w tajemnicy danych dotyczących pacjenta i jego choroby w następujących przypadkach:

1) tak stanowią ustawy; 2) badanie lekarskie zostało przeprowadzone na żądanie uprawnionych, na podstawie odrębnych ustaw, organów i instytucji; wówczas lekarz jest obowiązany poinformować o stanie zdrowia pacjenta wyłącznie te organy i instytucje; 3) zachowanie tajemnicy może stanowić niebezpieczeństwo dla życia lub zdrowia pacjenta lub innych osób; 4) pacjent lub jego przedstawiciel ustawowy wyraża zgodę na ujawnienie tajemnicy, po uprzednim poinformowaniu o niekorzystnych dla pacjenta skutkach jej ujawnienia; 5) zachodzi potrzeba przekazania niezbędnych informacji o pacjencie lekarzowi sądowemu; 6) zachodzi potrzeba przekazania niezbędnych informacji o pacjencie związanych z udzielaniem świadczeń zdrowotnych innemu lekarzowi lub uprawionym osobom uczestniczącym w udzielaniu tych świadczeń.

Problematyka zakreślona $\mathrm{w}$ temacie niniejszego artykułu wymaga zwrócenia uwagi również na przepis art. 27 k.e.l., w świetle którego: „Lekarz ma prawo do ujawnienia zauważonych faktów zagrożenia zdrowia lub życia w wyniku łamania praw człowieka". Z uwagi na fakt, że prawa człowieka, o których mowa w art. 27 k.e.l., nie są prawami nadawanymi w drodze decyzji organu administracji publicznej, ale wynikają z przyrodzonej i niezbywalnej godności człowieka, przywołany przepis należy rozpatrywać dwutorowo: z jednej strony jako uprawnienie lekarza, z którego może, ale nie musi skorzystać, z drugiej strony - jako obowiązek prawny, który wzmocniony został regulacjami pomieszczonymi m.in. w art. 162 k.k., których naruszenie zagrożone jest karą pozbawienia wolności do 3 lat.

Poruszona w niniejszym artykule problematyka upoważnia do zwrócenia uwagi na regulacje zawarte $w$ przepisach ustawy $\mathrm{z}$ dnia 6 czerwca 1997 r. - Kodeks postępowania karnego ${ }^{20}$. Zgodnie z art. 304 §1 k.p.k. każdy obywatel dowiedziawszy się o popełnieniu przestępstwa ściganego

19 Kodeks Etyki Lekarskiej przyjęty przez II Krajowy Zjazd Lekarzy dnia 14 grudnia 1991 r., https://www.nil.org.pl/_data/assets/pdf_file/0003/4764/ Kodeks-Etyki-Lekarskiej.pdf [dostęp: 25.04.2019 r.] (dalej: k.e.1.).

20 Ustawa z dnia 6 czerwca 1997 r. - Kodeks postępowania karnego, tekst jednolity: Dz. U. z 2018 r. poz. 1987 z późn. zm. (dalej: k.p.k.). 
z urzędu, ma społeczny obowiązek zawiadomić o tym prokuratora lub policję. Obowiązek ten zostaje wypełniony, jeśli udzielający pomocy lekarskiej dziecku lekarz podejrzewając popełnienie przestępstwa znęcania się na szkodę badanego małoletniego, zawiadomi o tym organy ścigania. Owo podejrzenie konkretyzuje się przy leczeniu obrażeń ciała, rozstroju zdrowia czy stwierdzaniu zgonu ${ }^{21}$. Z uwagi na fakt, że z przepisu art. 304 k.p.k. wynika jedynie społeczny obowiązek denuncjacji, brak złożenia $\mathrm{w}$ organach ścigania zawiadomienia o popełnionym przestępstwie znęcania się nad małoletnim, nie będzie skutkował pociągnięciem lekarza do odpowiedzialności karnej. Zdecydowanie odmiennie przedstawia się sytuacja, gdy informację o znęcaniu się nad małoletnim poweźmie instytucja państwowa lub samorządowa w związku ze swą działalnością. Oznacza to, że na pracownikach tychże instytucji będzie spoczywał obowiązek powiadomienia organów ścigania o podejrzeniu popełnienia przestępstwa ściganego z urzędu. Stąd też w dużej mierze to właśnie od współpracy pomiędzy lekarzem a organem ścigania będzie zależeć, czy sprawca przestępstwa z art. 207 k.k. zostanie ukarany, czy też nie. Lekarz zbierając wywiad szczególną uwagę powinien zwrócić na: brak wyjaśnienia dla urazu oraz brak zainteresowania ze strony rodzica bądź opiekuna dla sytuacji, która spowodowała obrażenia u dziecka; brak precyzyjnych informacji ze strony rodziców bądź opiekunów co do okoliczności, w których uraz nastąpił; brak reakcji na płacz dziecka związany z cierpieniem wywołanym urazem bądź nadmierne zainteresowanie dzieckiem w takiej sytuacji; lokalizację i rodzaje obrażeń ciała itp. Informacje przekazywane przez środki masowego przekazu pozwalają stanąć na stanowisku, że najrzadziej rozpoznawaną formą maltretowania dzieci jest wykorzystywanie seksualne, gdyż dzieci niezwykle rzadko ujawniają ten fakt. Takie zachowanie dziecka wynika przede wszystkim z obawy przed zemstą ze strony osoby, która wspomnianego czynu się dopuściła. Nie ulega wątpliwości, że przed ujawnieniem przez dziecko faktu wykorzystania seksualnego powstrzymuje je również wstyd. Oceniając materiał dowodowy organy ścigania powinny niezwykle wnikliwie przeanalizować i porównać dowody zgromadzone przez lekarza zbierającego wywiad oraz dowody zgromadzone $\mathrm{w}$ ramach czynności prowadzonych $\mathrm{z}$ urzędu, bowiem to od ich rzetelnej oceny będzie zależał wynik postępowania w sprawie o przestępstwo z art. 207 k.k.

\footnotetext{
${ }^{21}$ Szerzej na ten temat, zob. M. Nestorowicz, Prawo medyczne, Toruń 1997, s. 110.
} 


\section{Zakończenie}

Powyższe rozważania i przywołane regulacje upoważniają do stwierdzenia, że korzystanie przez dziecko z uprawnień gwarantowanych przez przepisy prawa - z jednej strony oraz zwolnienie lekarza $\mathrm{z}$ obowiązku zachowania w poufności danych dotyczących dziecka, $\mathrm{w}$ odniesieniu do którego istnieje prawdopodobieństwo, że zostało pokrzywdzone czynem zabronionym z art. 207 k.k. - z drugiej strony, powinny być zawsze rozpatrywane i oceniane z punktu widzenia owej nadrzędnej klauzuli, którą jest dobro dziecka. To właśnie z uwagi na dobro dziecka, które jest wyznacznikiem realizacji jego praw gwarantowanych przez akty prawne różnej rangi, prawodawca konstruuje przepisy karne przewidujące zakazy stosowania przemocy wobec dzieci. Wydawać by się mogło, że zjawisko przemocy wobec dzieci jest problemem szeroko rozpowszechnionym, a tym samym wykrywalność przestępstw wysoka. Należy wyrazić ubolewanie, że pomimo istnienia wielu instrumentów ochrony prawnej służących dobru dziecka, niestety tak nie jest. Oznacza to, że tzw. „,ciemna liczba” przestępstw z art. 207 k.k. powoduje, że dzieciństwo - najbardziej beztroski czas w życiu człowieka - staje się gehenną.

Słowa kluczowe: dziecko, dobro dziecka, znęcanie się, zespół dziecka maltretowanego

\section{Bibliografia}

\section{Źródła prawa}

Konstytucja Rzeczypospolitej Polskiej z dnia 2 kwietnia 1997 r., Dz. U. z 1997 r. Nr 78, poz. 483 z późn. zm. i sprost.

Konwencja o prawach dziecka, przyjęta przez Zgromadzenie Ogólne Narodów Zjednoczonych dnia 20 listopada 1989 r., Dz. U. z 1991 r. Nr 120, poz. 526 z późn. zm.

Dekret z dnia 22 stycznia 1946 r. o stosunkach rodzinnych, Dz. U. z 1946 r. Nr 6, poz. 52 z późn. $z m$.

Ustawa z dnia 25 lutego 1964 r. - Kodeks rodzinny i opiekuńczy, tekst jednolity: Dz. U. z 2017 r. poz. 682 z późn. zm.

Ustawa z dnia 5 grudnia $1996 \mathrm{r}$. o zawodach lekarza i lekarza dentysty, tekst jednolity: Dz. U. z 2019 r. poz. 537 z późn. zm.

Ustawa z dnia 6 czerwca 1997 r. - Kodeks karny, tekst jednolity: Dz. U. z 2018 r. poz. 1600 z późn. zm. 
Ustawa z dnia 6 czerwca 1997 r. - Kodeks postępowania karnego, tekst jednolity: Dz. U. z 2018 r. poz. 1987 z późn. zm.

\section{Orzecznictwo}

Postanowienie Sądu Najwyższego z dnia 11 lutego 1997 r., II CKN 90/96, Legalis nr 333272.

Postanowienie Sądu Najwyższego z dnia 12 grudnia 2000 r., V CKN 1751/00, Legalis nr 299530.

\section{Literatura}

Balcerek M., Prawa dziecka, Warszawa 1986.

Bryk J., Zagadnienie karcenia nieletnich jako okoliczności wyłaczającej bezprawność czynu (rozważania na tle przestępstwa znęcania się), "Przegląd Policyjny” 2001, nr 1, s. 57-66.

Kałdon B.M., Przemoc wobec dziecka w rodzinie. Studium empiryczne z zakresu kryminologii i prawa, Warszawa 2014.

Kulesza W., AIDS a prawnokarne problemy tajemnicy lekarskiej, [w:] A.J. Szwarc (red.), AIDS i prawo karne, Poznań 1996, s. 69-86.

Marzec-Holka K., Dzieciobójstwo - przestęstwo uprzywilejowane czy zbrodnia?, Bydgoszcz 2004.

Łopatka A., Dziecko, jego prawa człowieka, Warszawa 2000.

Łopatka A., Kto jest dzieckiem?, [w:] A. Łopatka (red.), Konwencja o prawach dziecka, a prawo polskie. Materiaty z konferencji naukowej zorganizowanej w gmachu Sejmu RP w dniach 19-20 marca 1991 r., Warszawa 1991, s. 17-25.

Meurer D., AIDS und strafrechtliche Probleme der Schweigepflicht, [w:] A.J. Szwarc (red.), AIDS und Strafrecht, Berlin 1996, s. 133-153.

Nestorowicz M., Prawo medyczne, Torun 1997.

Stojanowska W., Rozwód a dobro dziecka, Warszawa 1979.

Szymczak M. (red.), Słownik jezzyka polskiego, t. 1, Warszawa 1981.

Wachholz L., Dzieci jako ofiary znęcania się rodziców, „Przegląd Lekarski” 1908, nr 9, s. $1-10$.

\section{CHILD ABUSE SYNDROME AND THE OBLIGATION TO KEEP MEDICAL CONFIDENTIALITY}

\section{Sum mary}

Over the centuries, the problem of child abuse has been shaped in various ways. In ancient times, the father could and decided about the right to life of his children, for which he did not bear criminal responsibility. In the literature on the 
subject, the issue of the battered child's syndrome appeared only at the end of the 19th century. This article attempts to address this issue from the point of view of the institution of medical secrecy and the obligation of denunciation in the event of obtaining information signaling the offense under Art. 207 C.C.

Key words: child, welfare of the child, crime of abuse, Child Abuse Syndrome

\section{СИНДРОМ ИЗБИТОГО РЕБЕНКА И ОБЯЗАННОСТЬ ХРАНИТЬ ВРАЧЕБНУЮ ТАЙНУ}

\section{Резюме}

На протяжении веков проблематика причинения вреда ребенку формировалась по-разному. В древности именно отец мог и принимал решение о праве на жизнь своих детей, за что не нес уголовной ответственности. В научной литературе вопрос синдром избитого ребенка появилось только в конце XIX века. В настоящей статье сделана попытка обращения к этой проблеме с точки по отношению к организации врачебной тайне и обязанности денунциации в случае получения информации сигнала совершении преступления по ст. 207 уголовного кодекса.

Ключевые слова: ребенок, благосостояние ребенка, издевательства, синдром избитого ребенка 